Anders La Cour: Frivillighedens logik og dens politik - En analyse af den personrettede frivillige sociale indsats og statens frivillighedspolitik.

Nyt fra Samfundsvidenskaberne 2014

(184 sider)

Gennem mange år har Anders La Cour, som er lektor ved institut for Ledelse, Politik og Filosofi på Copenhagen Business School, været en engageret kommentator på frivillighedsfeltet med et kritisk blik for statens ledelse af frivilligheden. Frivillighedens logik og dens politik udgør et vigtigt, velskrevet og kritisk bidrag til diskussionen af, hvordan vi kan definere, undersøge og lede frivilligheden.

Bogen indledes med at påpege et misforhold mellem en næsten ukritisk hyldest til frivillighedens muligheder på den ene side og en påfaldende mangel på undersøgelser af, hvad frivillighed er for et socialt fænomen på den anden. Det er problematisk, påpeger La Cour, at staten siden 80'erne har søgt at alliere sig med, for siden at styre og opdrage frivilligheden, mens hverken politikere eller forskere har beskæftiget sig med, hvordan den sociale frivillige omsorg adskiller sig fra den, der udbydes på markedet eller af staten.

Bogen har således en række ambitioner. Dels en mere analytisk, der udfoldes i bogens første del, hvor La Cour, med fokus på den personrettede sociale frivillige indsats, undersøger frivillighedens sær- egne logik for på den baggrund, i bogens andel del, at diskutere, hvordan frivilligheden gøres til objekt for politisk styring, og hvordan denne styring kan være problematisk i lyset af frivillighedens særlige logik. Den centrale pointe er i den forbindelse, at frivillighedens logik, som den udfolder sig i den personrettede indsats, konstant bevæger sig mellem formel og uformel omsorg i sin afsøgning af, hvad der giver mening på interaktionens præmisser. Denne dynamik rummer på den ene side potentialer for fornyelse, men gør den samtidig vanskelig at lede på det organisatoriske og det politiske niveau. Derfor skal politikere og frivillige ledere undlade regelbunden styring, men i stedet praktisere en refleksiv ledelse og acceptere frivillighedens uforudsigelighed som en kvalitet.

En videre ambition med bogen er at bidrage til den danske og internationale forskning i frivillighed, der efter La Cours mening i overvejende grad udgøres af kvantitative studier, der ofte sætter lighedstegn mellem frivillighed og de aktiviteter, der rammesættes af frivillige organisationer, og desuden reducerer frivillighed til det, der udføres af frivillige. Disse to cirkelslutninger finder La Cour for det første anakronistiske, idet frivillighed nu til dags organiseres og udføres i andre sektorer end den frivillige. Desuden er cirkelslutningerne analytisk uproduktive, idet de blokerer for en mere eksplorativ undersøgelse af frivilligheden som socialt fænomen. På dette punkt vil jeg påpege, at der i hvert fald internationalt findes forskning, der undersøger 
frivillighed som socialt og interaktionistisk fænomen afkoblet bestemte organisationer og sektorer, og det kan undre, at La Cour i sin ellers omfattende afsøgning af feltet ikke er kommet forbi disse studier. Endvidere skal det med, at også den kvantitative danske forskning i frivillighed interesserer sig for frivillighed i ikkekonventielle former, som det kaldes i den seneste kortlægning af området. Så meget desto mere er La Cours projekt relevant; ikke mindst i en dansk kontekst, hvor der er godt brug for flere kvalitative og teoretisk kvalificerede undersøgelser af frivilligheden som socialitet.

En tredje ambition for bogen er at være en provokerende og inspirerende samtalepartner, der inviterer alle med interesse $i$ frivilligheden - praktikere såvel som forskere og politikere - til at se den gennem et nyt perspektiv, nemlig det systemteoretisk inspirerede som La Cour udvikler med inspiration fra den tyske sociolog Niklas Luhmann. Denne ambition indfries på alle måder i den tankevækkende og til tider ligefrem morsomme bog.

Valget af Luhmann som inspirator til det særlige blik på frivilligheden begrundes veloplagt i bogens første kapitel, hvor La Cour påpeger, at selvom der muligvis ikke er tale om nogen let tilgængelig teori, endsige en teoretiker der har beskæftiget sig direkte med frivillighed, så giver Luhmanns arbejde mulighed for at iagttage frivilligheden uden at forfalde til de føromtalte uproduktive cirkelslutninger. Især Luhmanns skelnen mellem organisatorisk og interaktionelt baseret omsorg inddrages i undersøgelsen af frivillighedens særlige logik. Mens den organisatorisk baserede, formelle omsorg er underlagt organisationens beslutninger og rolleforventninger, er den interaktionelt baserede, uformelle, omsorg nødt til at afsøge sine grænser på nærværets præmisser. Idet frivillighed på samme tid er henvist til nærværets præmisser for interaktion og til de formelle retningslinjer, som organisationen udstikker, er frivilligheden præget af en dobbelthed, der gør den vanskelig at indfange og lede.
Frivillighedens dobbelthed illustreres med empiriske nedslag (Kapitel 3) hentet fra fire udvalgte cases: Børns voksenvenner, patientstøtter, kontaktfamilier og besøgstjenester, der har det til fælles, at omsorgen er formelt organiseret men har mulighed for at udvikle sig på nærværets præmisser. Eksempler på de ledelses- og interaktionsmæssige kvaler denne dobbelthed kan medføre, hører vi i udvalgte interviewcitater med ledere, frivillige og en enkelt modtager af frivillige ydelser. Der er tale om 32 interviews udført fra 2002 til 2012. Overvejelser om udvælgelse og rekruttering af informanter bliver læseren ikke præsenteret for, men citaterne stammer overvejende fra ledere, mens vi hører mindre til de frivillige og modtagerne af indsatsen.

Bogens anden del går videre i en undersøgelse af, hvordan frivilligheden gøres til genstand for politisk styring. Kapitel 5 rummer et historisk rids over staten og frivillighedens relation, og skildrer, hvordan staten har konstrueret frivilligheden som sin modsætning for derefter at gøre den til selvstyrende objekt $\mathrm{i}$ tråd med statens målsætninger. Kapitel 6 indledes med en dramatisering af denne udvikling i afsnittet "Scener fra et dårligt ægteskab", der sammenfatter 30 års historie på knap 3 sider i en fortælling med paralleller til My Fair Lady og andre kærlighedshistorier om ambivalent fascination og disciplinering af det kaotiske. Det er ikke alle forundt at kunne beskrive en lang og kompliceret historisk udvikling, så man klukker tavst i stillekupeen under læsningen. La Cour påtager sig herefter rolle som parterapeut, der påpeger, hvordan staten i sin nuværende politik agerer selvmodsigende og uhensigtsmæssigt for det videre forhold, idet den på den ene side bejler til frivilligheden som sit attraktive modbillede i kraft af dens uforudsigelighed og informalitet, men samtidigt opstiller regler om performance management og anden standardisering.

Samlet set udgør Frivillighedens logik og dens politik en inspirerende og læseværdig bog. La Cour er ikke den første, 
der kritiserer statslig indføring af styringsteknologier, men jeg er begejstret over, at bogen lader kritikken tage afsæt i en kvalitativ analyse, der via konkrete eksempler fra akavede interaktioner viser os, hvordan en stram regulering kan være problematisk. Bogen fortjener desuden ros for sin ambition om at undersøge frivilligheden som socialt fænomen afkoblet de frivillige organisationer. Det skal blive spændende at følge de videre undersøgelser, der kommer ud af denne dagsorden. Endelig skal det fremhæves, at La Cour er en dygtig, vidende og engageret formidler, der mestrer den svære kunst at gøre et komplekst og tungt stof vedkommende, som i afsnittet "Scener fra et dårligt ægteskab".

I småtingsafdelingen for kritiske bemærkninger finder jeg bogens tendens til gentagelser. Særligt i Kapitel 4 og 5 havde jeg déjà vu. I den tungere afdeling er der et par metodiske valg, der undrer mig. La Cour indleder med en harsk kritik af den eksisterende forskning, der lader frivilligheden være et vedhæng til organisationsformen. Derfor kunne man have håbet på et mindre traditionelt case-valg $\mathrm{i} \mathrm{La}$ Cours egen undersøgelse, men som han skriver, er tre ud af de fire cases traditionelle frivillige organisationer. Spørgsmålet er derfor, om hans pointe vedrørende frivilligheden som selvstændigt socialt fænomen kommer helt hjem, når analysen tager afsæt i disse organisationer? Dette vil jeg lade læseren om at vurdere. Jeg savner i hvert fald at høre, hvad La Cours blik på frivilligheden kan udrette i mindre traditionelle kontekster. Videre i det metodiske spor undrer det mig, at $\mathrm{La}$ Cours interesse for frivilligheden som socialitet ikke omfatter socialiteten mellem de frivillige. Til trods for at fokus er på den personrettede indsats, er den socialitet, der kan antages at finde sted mellem de frivillige, underligt fraværende $i$ analysen, der primært rummer de frivilliges relation til modtagere af indsatsen og de frivilliges relation til organisationen. Endelig undrer det mig, at dem, som indsatsen er tiltænkt, ikke kommer mere til orde i interviewuddragene, når La Cour ligefrem indleder med at påpege, hvordan disse personer ofte udelades i det overvældende fokus på de frivillige. Forhåbentligt hører vi mere til denne gruppes oplevelser af frivilligheden fremover.

Uanset større og mindre kritiske bemærkninger præsenterer Frivillighedens logik og dens politik et veloplagt, kritisk og reflekteret forslag til et nyt blik på frivilligheden og et kvalificeret kritisk blik på et politisk system, der har lidt for travlt med at få frivilligheden til at performe i henhold til nogle politisk fastsatte kriterier. Jeg vil anbefale bogen til alle, der beskæftiger sig med frivillighed, og som har lyst til at kaste et nyt blik på feltet.

\section{Ane Grubb}

Institut for Sociologi og Socialt Arbejde

Aalborg Universitet

\section{Torben Fridberg og Lars Skov Henriksen (red): Udviklingen i frivilligt arbej- de 2004-2012.}

SFI - Det Nationale Forskningscenter for Velfærd 2014 (304 sider)

Det er altid med en vis spænding, at man læser undersøgelser, der sigter mod at beskrive og analysere samfundsmæssige forandringer. Dette gælder også frivillighedsområdet. Redaktører og forfattere til rapporten Udviklingen i frivilligt arbejde 2004-2012 har bidraget med nye og interessante data og spændende analyser af udviklingen i det frivillige arbejde i Danmark.

Det særlige ved de data, som ligger til grund for rapporten, er først og fremmest, at der er tale om paneldata. Det muliggør analyser af forandringer på individniveau, og dermed kan undersøgel- 
sen bidrage til at besvare spørgsmål om forandringer, som gentagne tværsnitsundersøgelser ikke kan. Herudover tager forfatterne også fat på nogle delvist underbelyste områder i dansk frivillighedsforskning, nemlig de ikke-konventionelle former for frivilligt engagement, frivillighed hos ikke-vestlige indvandrere, det uformelle frivillige arbejde, pengegaver samt betydningen af organiseret uddannelsesmæssig kvalificering af frivillige.

I rapporten viser Torben Fridberg, at der overordnet set findes en stor grad af stabilitet $\mathrm{i}$ det frivillige arbejde. I begge undersøgelsesår 2004 og 2012 tilkendegiver en tredjedel af respondenterne $\mathrm{i}$ undersøgelsen, at de udfører frivilligt arbejde. Men under den stabile overflade lurer nogle interessante forandringer, som måske er et lille varsel om fremtidige tendenser: Andelen af frivillige er blevet lidt mindre hos de yngste og lidt større hos de ældste borgere. Selvom der ikke er tale om deciderede krisetegn, så kan det være et tegn på, at der med tiden opstår generationsbetingede lavkonjunkturer i frivilligheden.

Et andet interessant tema, som undersøges af Lars Skov Henriksen, er spørgsmålet om, hvorvidt frivilligheden i fremtiden løsrives fra foreningerne og forskydes over mod en større grad af uformel, episodisk frivillighed, som relaterer sig til den offentlige og private sektor. Det ikke-medlemsbaserede frivillige arbejde er særligt udbredt i den yngre del af befolkningen, som i øvrigt ser ud til at have en mere pragmatisk holdning til, hvilken sektor det frivillige arbejde organiseres i. Den klassiske forenings- og organisationsmodel er således mindre rodfæstet blandt de unge. Dette kan selvsagt skyldes, at de unge - givet deres livssituation - er fleksible i deres valg af frivilligt arbejde. Fremover bliver det interessant at undersøge, i hvilket omfang disse aldersforskelle skyldes livscyklus eller måske udgør kimen til nogle mere omfattende generationsbestemte forandringer.

Morten Frederiksen og Rasmus Juul Møberg fremhæver netop i deres kapitel, at graden af frivilligt arbejde er dynamisk og følger forskellige livsfaser og begivenheder i livet. De viser dog også, at der er betydelige kohorteforskelle, hvor den ældste kohorte markerer sig ved at være den som udfører mest frivilligt arbejde. Socialiseringsperspektivet inddrages også, og resultaterne fra undersøgelsen viser blandt andet, at tradition for frivilligt arbejde i familien har stor betydning for, om frivilligheden gives videre til de kommende generationer. Der er med andre ord noget der tyder på, at frivilligheden går i arv. Selvom det muligvis er vanskeligt at belyse med de indsamlede data, så ville det være interessant med nogle bud på hvilke sociale mekanismer der er på spil her.

Undersøgelsen giver på baggrund af den særlige del-undersøgelse af ikkevestlige indvandrere også et værdifuldt grundlag for analyser af, hvorvidt borgere med indvandrerbaggrund er frivillige på andre måder end indfødte danskere. Hans-Peter Qvist viser, at der er forskelle på danskeres og ikke-vestlige indvandreres omfang af frivilligt arbejde, selv når der tages højde for sociale og ressourcemæssige forskelle. En væsentlig pointe er her, at ikke-vestlige indvandrere i mindre omfang end indfødte danskere er blevet spurgt, om de vil medvirke i frivilligt arbejde. Nogle at de interessante spørgsmål, som fortjener at blive belyst yderligere, er, hvilken rolle sociale netværk og rekrutteringsmønstre spiller, og herunder også om sproglige færdigheder og religion har betydning i denne sammenhæng?

Thomas P. Boje undersøger frivilligt arbejde, som udføres under uformelle sociale rammer. Disse former for frivillighed finder dog primært sted i familiære sammenhænge. Analyserne og undersøgelserne i rapporten viser blandt andet, at uformel praktisk hjælp og uformel økonomisk støtte primært går fra de ældre generationer til deres børn hos de dansk fødte respondenter, mens det omvendte til dels er tilfældet for ikke vestlige indvandrere. Temaet er ganske interessant, også selvom disse intra-familiære for- 
mer for hjælp umiddelbart udfordrer de etablerede forståelser af hvad frivilligt arbejde er. I analyserne ville det også være gavnligt med en klar sondring mellem de former for hjælp der gives til henholdsvis slægt, naboer og venner. Specielt kategorien naboer ville være oplagt at isolere i fremtidige studier af hvilken rolle by- og beboelsesmæssige forhold spiller for engagement $i$ uformelt frivilligt arbejde.

De seneste år har frivillighed som bekendt haft stor offentlig bevågenhed. Heraf følger også en øget interesse for uddannelse og kvalificering af frivillige. Både i det offentlige og i mange frivillige foreninger diskuterer man derfor relevansen og betydningen af kvalificeringsforløb for frivillige. Bjarne Ibsen viser her, at der findes en række forskelle på, hvor meget forskellige typer af foreninger tilbyder kurser til de frivillige, og hvor stor formaliseringsgraden af kurserne er. De mest interessante analyser i denne del af rapporten handler imidlertid om, hvilken betydning kurser og uddannelsesaktiviteter har for lysten til at fortsætte det frivillige arbejde. Her viser analyserne, at deltagelsen i forskellige former for uddannelses- og kursusaktiviteter styrker lysten til at fortsætte som frivillig. Kvaliteten i det frivillige arbejde, som udføres, afhænger dog i stor grad af, at institutioner og foreninger formår at rekruttere personer med relevante erfaringer og kvalifikationer.

Rapportens omfang og kvalitet taget $i$ betragtning er der nærmere tale om en videnskabelig antologi. Bidragene indeholder både deskriptive og grundige multivariate statistiske analyser samt referencer til den skandinaviske og internationale frivillighedslitteratur. Med den relativt brede spændvidde i rapportens forskellige kapitler kunne der med fordel gennemføres tværgående analyser af udviklingstendenserne. Eksempelvis ville det være oplagt at styrke kønsperspektivet, idet flere af analyserne jo dokumenterer, at der (fortsat) er forskel på mænd og kvinders frivillige engagement - både på tværs af forskellige områder (f.eks. idræt, kultur, socialt hjælpearbejde), og på tværs af de forskellige organiseringsformer (f.eks. formelt og uformelt frivilligt arbejde). Hvad skyldes disse forskelle og bliver de stærkere eller svagere over tid?

Som allerede nævnt, så er det især det oparbejdede datasæt som ligger til grund for rapporten, der fortjener opmærksomhed, og selvom det indtil videre er en relativ kort periode på otte år, der er undersøgt, så er grunden lagt til flere opfølgende undersøgelser og ganske sikkert flere interessante publikationer.

\section{Klaus Levinsen}

Institut for Statskundskab

Syddansk Universitet 